\title{
Carbon storage allocation characteristics of Platycladus orientalis plantation ecosystem with different densities
}

Du Y.*

Environmental Design, School of Textile Apparel and Art Design, Yuanpei College, Shaoxing University, Shaoxing 312000, China Received: 01/07/2020, Accepted: 04/08/2020, Available online: 22/10/2020

*to whom all correspondence should be addressed: e-mail: 474692980@qq.com https://doi.org/10.30955/gnj.003379

\section{Graphical abstract}

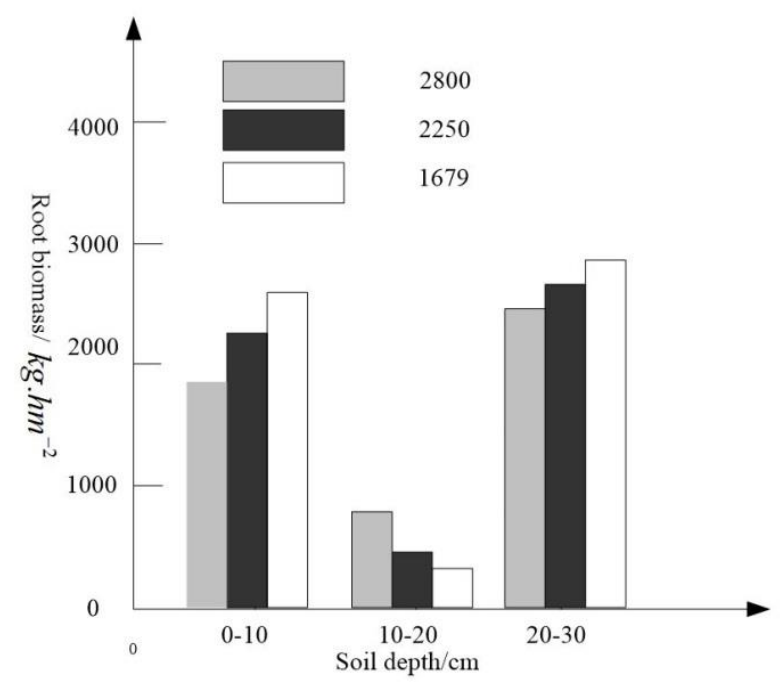

\section{Abstract}

Purpose: To research the influence of different densities of Platycladus orientalis plantation on the allocation characteristics of carbon storage in the ecosystem, the density regulation experiment on the Pinus massoniana plantation with different densities was carried out to discuss the change of the carbon storage of the ecosystem. Method: The density regulation experiment was carried out using random block design along contour line. Through the estimation of tree layer biomass of single Pinus massoniana, the determination of the carbon storage in the tree layer of Pinus massoniana, the estimation of the understory shrub, the grass layer, and the wood layer, the determination of carbon storage in vegetation and litter layer under forest, the determination of organic carbon content and carbon storage in the sample, and the carbon storage of the plantation ecosystem of different stand density sample plots, the effects of stand density on biomass and carbon storage of Pinus massoniana plantation were analyzed. Results: The results of average carbon storage per unit area of Pinus massoniana plantation was different stand densities are $94.11 \mathrm{t} / \mathrm{tm}^{2}$

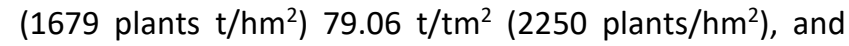

$73.32 \mathrm{t} / \mathrm{tm}^{2}$ (2800 plants $\left./ \mathrm{hm}^{2}\right)$. With the increase of stand density, the proportion of carbon storage in Pinus massoniana plantation decreased. This is because the larger the stand density, the more trees with small and medium diameter are grown in the Pinus massoniana plantation. The average diameter at breast height of the stand is very small, and the biomass of single tree decreases. The density 1566 plants $/ \mathrm{hm}^{-2}$ is most beneficial to the improvement of the carbon storage of the tree layer. Conclusions: Density regulation promotes the accumulation of carbon storage of the Pinus massoniana plantation and increases the carbon storage of understory vegetation, litter, and soil layer.

Keywords: Different density, Platycladus orientalis, plantation, ecosystem, carbon storage, allocation characteristics.

\section{Introduction}

Global warming is one of the most concerned environmental problems. More than $80 \%$ of $\mathrm{CO}_{2}$ comes from urban emissions. In recent years, the increase of $\mathrm{CO}_{2}$ concentration is about $28 \%$, which is one of the main factors leading to global warming. Forest is the largest carbon pool in the terrestrial ecosystem, and forest carbon storage accounts for $46.27 \%$ of the total amount of the global terrestrial carbon pool, and its soil carbon accounts for about $73 \%$ of the global organic carbon pool in the global soil. Forest plays an irreplaceable role in the process of global climate change, and has the functions of source, sink, and storage (Cicuzza et al., 2010). The plantation plays an important role in forest ecosystem, ecological protection, environmental safety, and timber supply (Gonzalez-Trinidad et al., 2017; Kim et al., 2018; Sanchez Camacho and Martinez Morales, 2017; Vicente-Molina et al., 2018). The function of carbon sink is a mechanism and effective choice to mitigate global climate change. It is of great significance to strengthen the carbon storage change, prediction, assessment, and productivity maintenance of plantation ecosystem (Ahamed et al., 2018; Mocan et al., 2018; Muhammad Tariq et al., 2019). 
Carbon storage in the forest ecosystem is related to management practices such as tree species, fertilization, rotation, and thinning. The carbon storage of the tree layer increases with stand density increasing (Liu, 2017; Wang et al., 2018). The density and soil carbon storage of Pinus elliottii plantation are inversely proportional to stand density. There are still differences in relation between soil carbon storage and stand density of the plantation (Keshavarzi and Kumar, 2020; Ma et al., 2015). As the main body of the terrestrial ecosystem, forest has a wide distribution area, with the highest biological productivity and the largest accumulation of biomass, and its biomass accounts for about $85 \%$ of the land biomass, and the carbon storage accounts for about $80 \%$ of the terrestrial biosphere carbon storage and $40 \%$ of the underground carbon storage. Forest vegetation has strong sustainability and stability in structure and function, and plays an important role in biogeochemical cycling. Forest growth absorbs $\mathrm{CO}_{2}$ and has a long-term preservation capacity. It plays the role of huge biological pump in regulating carbon exchange between terrestrial ecosystem and atmospheric carbon pool (Al-zaqri et al., 2017; Bell et al., 2018; Bharati et al., 2020; Khaleel et al., 2018; Nisavic et al., 2018). The relationship between biomass, litter, decomposition and accumulation, soil organic matter, and forest productivity in the forest ecosystem determines the carbon storage and carbon exchange. Therefore, biomass and productivity research has always been the main content of ecosystem carbon balance (Fischer et al., 2016). As an important part of terrestrial forest ecosystem, the plantation plays an important role in the restoration and reconstruction of ecological environment and economic development. Pinus massoniana is one of the main tree species for afforestation in barren hills in South China. The whole tree has high comprehensive utilization rate, fast growing, high yield, and strong adaptability, which has important position in papermaking raw materials and turpentine (Boudreault et al., 2015; Gohar et al., 2019). The effects of thinning on the growth, productivity, plant diversity, wood properties, and carbon storage of plantation were researched at home and abroad. However, the research on sustainable forest management and forest carbon sink is rather deficient. In this paper, the density regulation experiment on the Pinus massoniana plantation with different densities was carried out to discuss the change of carbon storage in the ecosystem, which provides reference for the sustainable management, carbon sink and development of Pinus massoniana plantation.

\section{Materials and methods}

\subsection{Basic situation of research area}

\subsubsection{Basic situation}

Xuzhou is located in the northwestern part of Jiangsu Province, the junction of the four provinces of Jiangsu, Shandong, Henan, and Anhui provinces. The geographical position is between $160^{\circ} 22^{\prime}-118^{\circ} 40^{\prime}$ in the east longitude $33^{\circ} 43^{\prime}-34^{\circ} 58^{\prime}$ in the north latitude. The city is mainly plain. The plain accounts for $92 \%$ of the total area, and hilly land accounts for about $8 \%$. Most of them are flat hound land, and mountainous area accounts for only 30 thousand hectares. Most of them are limestone residual dunes, which are 400 meters above sea level (Maksimova and Abakumov, 2015). There are a few hillock and hillock in the middle and east of the city. In this paper, the sampling plots of Pinus massoniana plantation are mainly distributed in hilly areas near the urban area of Xuzhou.

The tectonics of Xuzhou belongs to the southern part of the North China fault block area, and belongs to the southern margin of the North China seismic zone in seismic zoning. Geological condition and geological structure are not very complicated, and the frequency and intensity of seismic activities are relatively low. From the viewpoint of crustal structure, the crustal thickness of Xuzhou is relatively small.

\subsubsection{Climate}

The climate of the research area belongs to the warm temperate semi-humid monsoon climate. The solar thermal resource is abundant. The rain and heat are in the same period. The temperature difference between the day and night is large and the monsoon is obvious. It has four distinctive seasons, the average annual temperature of 13 to 16 degrees Celsius. The annual sunshine hours are 2284-2495 h, the annual frost free period is $200-220 \mathrm{~d}$, the annual average precipitation is $800-900 \mathrm{~mm}$, and the rainy season precipitation accounts for $56 \%$ of the whole year. The climate resource is superior, which is good for crop growth (Anderegg et al., 2015; Isfarita et al., 2019). The main meteorological disasters are drought, flood, wind, frost, freezing, hail, etc. Zonal vegetation is deciduous broadleaved mixed forest.

\subsubsection{Soil}

In the research area, the soil layer is barren and the bare rock rate is high. The soil type is coarse bone brown soil and leaching brown soil formed by limestone. Most soils have no lime reaction, low humus, and poor ability to maintain water and fertilizer (Zhang et al., 2016). The measurement results show that the content of organic matter is $0.6-0.8 \%$, the content of nitrogen is $0.098 \%$ $0.111 \%$, the available phosphorus $7.6 \%-17.4 \%$, the available potassium $60.0-72.5 \mathrm{ppm}$, the $\mathrm{pH}$ value of the soil $7.63-8.07$, and the salt $0.49-1.96 \mathrm{~g} / \mathrm{kg}$. The soil is extremely poor.

\subsection{Experiment design}

In the spring quarter of 2016 , the plot was used for soil preparation with holes. The size of the planting hole was $40 \mathrm{~cm} \times 30 \mathrm{~cm} \times 30 \mathrm{~cm}$. One year old bare root seedlings are used for afforestation and the row spacing is $2 \mathrm{~m} \times 2.3$ $\mathrm{m}$. The ways of tending are knife caress and hoe caress (Lun et al., 2018). It is tended 3a (Two times a year). In the autumn of 2017, density regulation experiments were carried out using random block design along contour lines. The four density treatments of the high density $\left(\mathrm{H}: 2800\right.$ plants $\left.\cdot \mathrm{hm}^{-2}\right)$, the medium density(M: 
2250 plants $\cdot \mathrm{hm}^{-2}$ ), and the low density (L: 1679 plants $\cdot \mathrm{hm}^{-2}$ ), and non-thinning (CK: 2016 plants $\cdot \mathrm{hm}^{-2}$ ) are set (Igu and Marchant, 2016). The distribution of Pinus massoniana corresponding to the first three densities is shown in Figure 1. Repeat 3 times, and the area of the plot is $30 \mathrm{~m} \times 20 \mathrm{~m}$. Investigations on forest carbon storage of the 4 treatments with 3 repetitions are selected, as shown in Table 1.

Through the estimation of tree layer biomass of single Pinus massoniana (Ibrahim et al., 2020; Shrestha et al., 2015), the determination of the carbon storage in the tree layer of Pinus massoniana, the estimation of the understory shrub, the grass layer, and the wood layer, the determination of carbon storage in vegetation and litter layer under forest, the determination of organic carbon content and carbon storage in the sample, and the carbon storage of the plantation ecosystem of different stand density sample plots, the effects of stand density on biomass and carbon storage of Pinus massoniana plantation are discussed (Schmerbeck and Fiener, 2015). The reason is analyzed, and theoretical support is provided for tending and management of Pinus massoniana plantation.

\subsubsection{Estimation of biomass of the tree layer}

The diameter at breast height and tree height of Pinus massoniana in the standard plot are measured. By using the fitted biomass model and survey data of tree measurement factors of sample plots (Spielvogel et al., 2016), the biomass and carbon storage of the tree layer of plantation stand are estimated, as shown in Table 2. In Table 2, D represents the diameter at the breast, and the $\mathrm{H}$ represents the height of the tree.

\subsubsection{Determination of carbon storage of the tree layer of Pinus massoniana}

By using the data of every tree, the sample near standard stand tree is selected to determine the carbon storage. 1 standard sample (4 plants) is selected in each plot. The fresh weight of the trunk, the barks, the branches, and the leaves was measured by cutting down standard sample. The underground root is measured by using the full digging method, and the fresh weights of the main root and lateral root are determined separately (Fei et al., 2017; llyas et al., 2019). For all organs, $200 \mathrm{~g}$ fresh samples are taken back to the laboratory, drying at constant temperature of 80 degrees Celsius for constant mass, and the fresh weight of each organ is converted into dry weight. The dried samples were then ground into $2 \mathrm{~mm}$ powder to measure the organic carbon content, and then the average carbon density of tree layer was estimated by average standard sample.

\subsubsection{Estimation of biomass of shrub, grass layer, and litter layer under the forest}

In the selected standard plot, the biomass of the grass layer and litter layer under the forest were determined by quadrat harvest method (Yuan et al., 2017). In each standard plot, three $2 \mathrm{~m} \times 2 \mathrm{~m}$ and $1 \mathrm{~m} \times 1 \mathrm{~m}$ quadrats were used to measure the biomass of shrubs and grass Table 1. Sample plot trees by diagonal method. Five $20 \mathrm{~cm} \times 20 \mathrm{~cm}$ quadrats were used to measure the biomass of litter. The collected samples were taken back to the laboratory and dried at 80 degrees Celsius until constant weight. Then the biomass was measured.

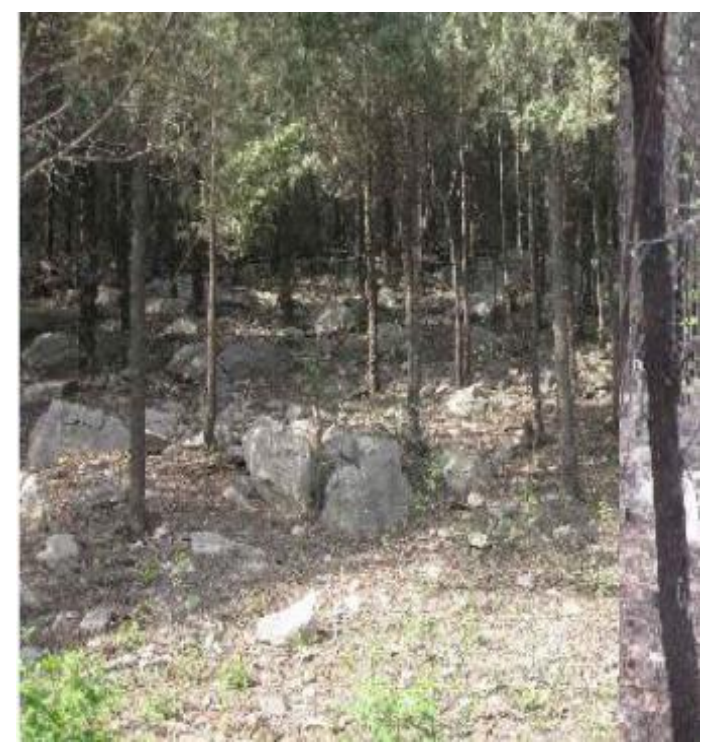

(a) 1679 plants $\cdot \mathrm{hm}^{-2}$

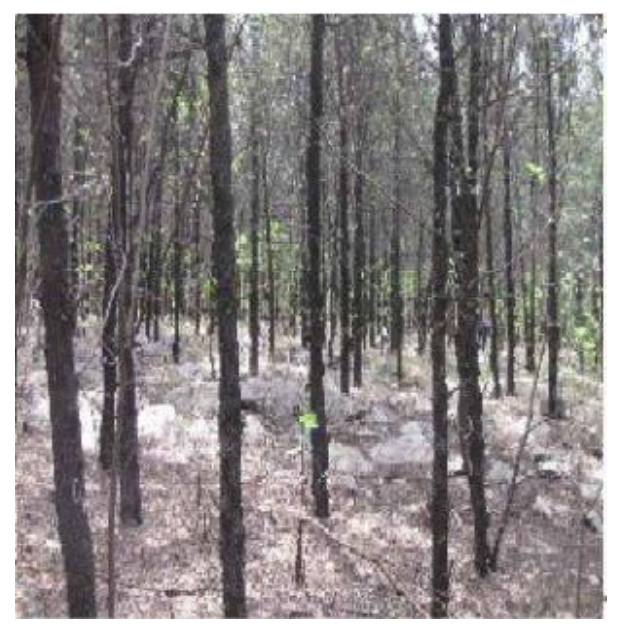

(b) 2250 plants $\cdot \mathrm{hm}^{-2}$

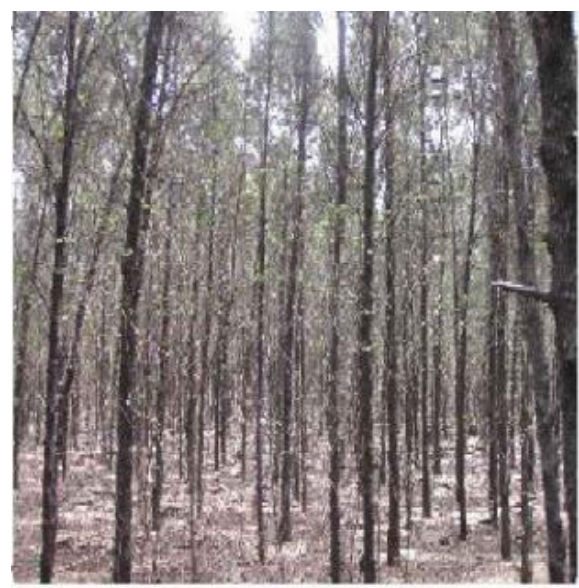

(c) 2800 plants $\cdot \mathrm{hm}^{-2}$

Figure 1. A survey of the forest stand of Pinus massoniana with different stand density 


\begin{tabular}{cccccccc}
\hline Handle & $\begin{array}{c}\text { Altitude } \\
(\mathbf{m})\end{array}$ & $\begin{array}{c}\text { Slope } \\
\mathbf{(}^{\mathbf{}} \mathbf{n}\end{array}$ & $\begin{array}{c}\text { Vegetation } \\
\text { coverage }\end{array}$ & $\begin{array}{c}\text { Canopy } \\
\text { density }\end{array}$ & Average DBH $(\mathbf{m})$ & $\begin{array}{c}\text { Average tree } \\
\text { height }(\mathbf{m})\end{array}$ & $\begin{array}{c}\text { Post cutting density } \\
\left(\mathbf{p l a n t s} \cdot \mathbf{h m}^{-2}\right)\end{array}$ \\
\hline $\mathrm{H}$ & 760 & 33 & 0.87 & 0.92 & 11.68 & 8.89 & 2800 \\
\hline $\mathrm{M}$ & 790 & 30 & 0.89 & 0.9 & 12.86 & 9.11 & 2250 \\
\hline $\mathrm{CK}$ & 769 & 27 & 0.9 & 0.88 & 12.93 & 9.42 & 2016 \\
\hline $\mathrm{L}$ & 815 & 23 & 0.88 & 0.91 & 12.86 & 9.31 & 1679 \\
\hline
\end{tabular}

\subsubsection{Determination of carbon storage of vegetation and litter layer under forest}

According to the diagonal line, 3 shrub quadrats (area 2 $\mathrm{m} \times 2 \mathrm{~m}$ ) and 3 herb quadrats (area $1 \mathrm{~m} \times 1 \mathrm{~m}$ ) were set up in the plot, and the names of the species in each quadrat were recorded. The fresh weights of the biomass and of aboveground and underground shrub grass were measured by harvest method ( $\mathrm{Hu}$ et al., 2016; Ogwah and Eyankware, 2020). Samples from different plants with the same organ were collected 200 g (1/3 in the upper, middle and the lower), and the moisture content and carbon content were measured in the laboratory. The biomass of the litter with 1 square meters is measured. $200 \mathrm{~g}$ mixture samples were taken back to the laboratory to dry until constant weight, and the carbon storage of each component was calculated by the ratio of water content and carbon content.

\subsubsection{Determination of organic carbon content and carbon storage in the sample}

Sample collection: The soil sample is randomly collected in the sampling area according to the $S$ route. After collection, the soil samples are mixed. The quartering method is used to take the samples. 3 samples of fresh soil are taken from each plot and dried. The soil moisture content is measured. Another enough soil samples were taken in the sealed bags, and then returned to natural air drying for one month. Then soil was screened for $2 \mathrm{~mm}$ soil and the organic carbon is determined. 3100 $\mathrm{cm}^{3}$ ring-knives are taken for the determination of soil capacity. The organic carbon content in soil and plant samples is determined by potassium dichromate hydration heating method. Data is calculated and chart made by using WPS2010 (Mackay and Band, 2015). Single factor analysis of variance (one-way ANOVA) was processed by SPSS 21 . The estimation of soil carbon storage is the product of soil thickness, soil density, and carbon content in each soil layer.

\subsubsection{Calculation of carbon storage of the plantation ecosystem}

The carbon content of organs of Pinus massoniana plantation is: trunk $(47.33 \%)>$ leaf $(43.91 \%)>$ branch (43.45\%) > root (42.95\%) (Yan et al., 2015). The average carbon content of the aboveground part is $44.89 \%$, and the average carbon content of the whole plant is $44.41 \%$.

The carbon content rate of understory shrub layer and litter is obtained by using common 0.45 carbon conversion rate (IPCC, 2003).

Carbon storage is calculated by the product of the dry matter weight per unit area (biomass) and its carbon content (Mjöfors et al., 2017).
Plant carbon storage $\left(\operatorname{tghm}^{2}\right)=$ plant biomass $\left(\operatorname{tghm}^{2}\right) *$ carbon content rate (\%)

Soil organic carbon storage $\left(\mathrm{tghm}^{-2}\right)=$ soil organic carbon content $\left(\mathrm{g} / \mathrm{hm}^{2}\right) *$ bulk density $\left(\mathrm{g} / \mathrm{cm}^{3}\right)^{*}$ soil thickness $(\mathrm{cm}) * 10^{-1}$.

Table 2. Biomass estimation model

\begin{tabular}{ccc}
\hline Project & Biomass equation & $\begin{array}{c}\text { Correlation } \\
\text { coefficient }\end{array}$ \\
\hline Dry weight & $y=0.0573\left(D^{2} H\right)^{0.8657}$ & 0.97 \\
\hline $\begin{array}{c}\text { Branch } \\
\text { weight }\end{array}$ & $y=0.0043\left(D^{2} H\right)^{1.1085}$ & 0.89 \\
\hline Leaf weight & $y=0.0038\left(D^{2} H\right)^{1.0385}$ & 0.84 \\
\hline Root weight & $y=0.0485\left(D^{2} H\right)^{0.6886}$ & 0.80 \\
\hline
\end{tabular}

\section{Results and discussion}

3.1. Biomass and allocation of aboveground vegetation and litter layer in Pinus massoniana plantation with different stand densities

\subsubsection{Analysis on the biomass of single plant of Pinus massoniana}

According to the analysis results, the stand density has a significant effect on the average biomass of single plant of Pinus massoniana. The relationship can be expressed by the exponential function $Y=189.72 e^{-0.0008 x}\left(R^{2}=0.9856\right.$ ), as shown in Figure 2 (Hao et al., 2015). The greater the density of the stand, the smaller the average biomass of the single plant. The average biomass of single plant of Pinus massoniana in the sample plot with the highest density (2800 plants $/ \mathrm{hm}^{2}$ ) is $18.88 \mathrm{~kg}$. The average biomass of single plant of Pinus massoniana in the sample plot with the smallest density (1679 plants $/ \mathrm{hm}^{2}$ ) is $45.36 \mathrm{~kg}$.

From Figure 3, it can be seen that, the biomass of each plant of Pinus massoniana is trunk $>$ branch $>$ root $>$ leaf. The biomass of all organs in the tree layer has the same trend. The proportion of trunk biomass is more than $50 \%$, and the biomass of each organ decreases with the increase of stand density. The average trunk biomass of single plant in the low density stand (1679 plants $/ \mathrm{hm}^{2}$ ) is 1.26 times higher than that of the high density stand (2800 plants $/ \mathrm{hm}^{2}$ ). For the branch, it is 1.59 times, for the leaf, it is 1.49 times, and for the root, it is 1.06 times. Biomass distribution of different organs of Pinus massoniana stands relatively stable in different stand densities. The range of variation of trunk, branch, leaf, and root is between $53.30 \%-55.48 \%, 17.94 \%-21.79 \%$, $10.40 \%-11.81 \%$ and $13.1 \%-16.18 \%$, respectively. 


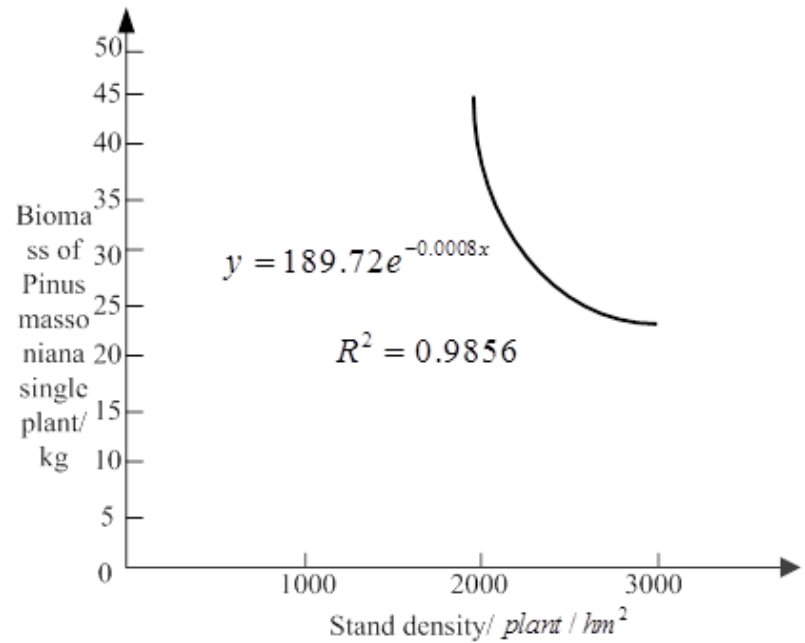

Figure 2. The relationship between average plant biomass and stand density

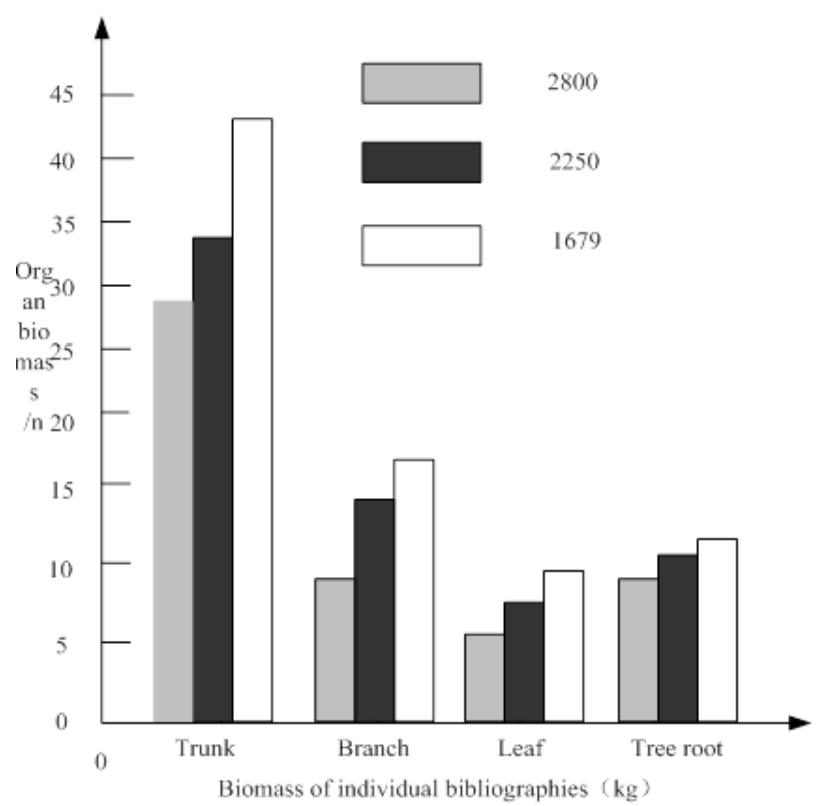

Figure 3. Changes in biomass per plant per plant with stand density

From Figure 4., it can be seen that, the response of fine root biomass to stand density is consistent with that of tree layer, soil layer and ecosystem carbon storage under different stand densities. The highest value appears in low stand density plot, and the lowest value appears in high stand density plot. Therefore, the correlation between fine root biomass and soil carbon storage is larger than that of tree layer carbon storage or system carbon storage. With the decrease of stand density, the length of fine root grows first, which indicates that the function of fine root to absorb water and nutrients is strengthened. The diameter of the higher root in the fine roots is thicker, the carbon distribution is increased, and the transport and the ability to extend deeper into the soil are enhanced. It is to promote the rapid growth of aboveground tree and the increase of the carbon storage of tree layer. With the continue decrease of the stand density, the life of the lower root in the fine roots becomes shorter, the decomposition and turnover speed increase, and the carbon storage in the soil layer increases significantly. It shows that low density does not weaken the carbon sink capacity of the stand. This is because the density of the stand is too large and the nutrient space of the stand is relatively small, which suppresses the increase of the biomass of the stand, and the low density makes the stand have a relatively sufficient nutrient space, accelerates the accumulation of the biomass of the stand, and increases the carbon storage of the stand (Viglietti et al., 2015). Therefore, a reasonable stand density can not only increase the carbon storage of tree layer, but also increase the carbon storage of the whole ecosystem.

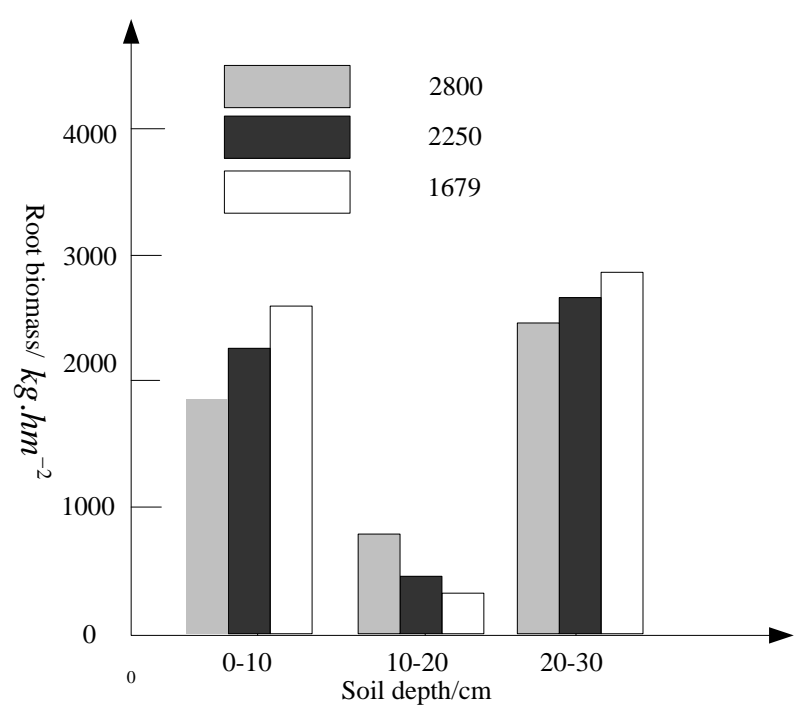

Figure 4. Changes in biomass of different stand density root

3.1.2. Analysis of biomass change of tree layer in Pinus massoniana with different densities

From Table 3, it can be seen that, the biomass of organs in Pinus massoniana plantation is trunk $>$ branch $>$ root $>$ leaf. The average trunk biomass accounts for $54.29 \%$ of the biomass of the whole tree layer. The biomass of organs in Pinus massoniana decreases with the increase of stand density. The proportion of the biomass of trunk and root increases in high-density forest. The proportion of the biomass of branch and leaf gradually decreases in high-density forest. It shows that intraspecific competition caused by excessive density affects the elongation of Pinus massoniana branches and leaves. This result is consistent with the research results of other scholars on Pinus elliottii and Pinus massoniana. The number in the bracket is the percentage of the biomass of each organ in the biomass of Pinus massoniana.

\subsubsection{Biomass and allocation of vegetation and litter in Pinus massoniana plantation with different stand densities}

The relationship of Pinus massoniana stands with different stand densities is shown in Table 4. The higher density the Pinus massoniana stand, the lower the total biomass per unit area. The average total aboveground biomass is $71.77 \mathrm{tghm}^{-2}$. The biomass of tree layer is the most important component of total aboveground 
biomass, which accounts for $92.06 \%$ of the total biomass, and the second maximum is litter biomass, which accounts for $2.91 \%$. The biomass of understory vegetation (shrub and grass) decreases with the increase of the stand density. The main reason is that the increase of stand density reduces the light intensity inside the forest, and increases competition within species, and suppresses the elongation of understory vegetation and shrubs. The thinning soil layer of Pinus massoniana plantation is also an important factor affecting the biomass allocation of understory vegetation. The number in the bracket is the percentage of the biomass of each organ in the total biomass of aboveground layer.

Table 3. Biomass of tree layer in Platycladus orientalis plantation with different densities

\begin{tabular}{|c|c|c|c|c|c|}
\hline \multirow{2}{*}{ Index } & \multirow{2}{*}{ Component } & \multicolumn{3}{|c|}{ Stand density (plant.hm²) } & \multirow{2}{*}{ Average } \\
\hline & & 1679 & 2250 & 3074 & \\
\hline \multirow{5}{*}{ Biomass $\left(\mathrm{t} \cdot \mathrm{hm}^{2}\right)$} & Trunk & $40.59(53.30)$ & $34.92(54.55)$ & $32.19(55.48)$ & 35.57 \\
\hline & Branch & $16.60(21.79)$ & $12.61(19.70)$ & $10.14(17.94)$ & 25.74 \\
\hline & Leaf & $9.00(11.81)$ & $7.08(11.07)$ & $6.04(10.40)$ & 23.22 \\
\hline & Tree root & $9.98(13.10)$ & $9.40(14.68)$ & $9.39(16.18)$ & 24.17 \\
\hline & Total & 76.16 & 64.02 & 58.03 & 66.07 \\
\hline
\end{tabular}

Table 4. Biomass and distribution at different levels of Pinus massoniana plantations with different densities

\begin{tabular}{cccccc}
\hline & Component & \multicolumn{3}{c}{ Stand density } & Average \\
\cline { 2 - 6 } & & $\mathbf{1 6 7 9}$ & $\mathbf{2 2 5 0}$ & $\mathbf{3 0 7 4}$ & \\
\hline \multirow{4}{*}{ Biomass } & Tree & $76.16(89.30)$ & $64.02(94.09)$ & $58.03(93.67)$ & $66.07(92.06)$ \\
\cline { 2 - 6 } & Shrub & $3.04(3.56)$ & $1.16(1.70)$ & $1.91(3.08)$ & $2.04(2.84)$ \\
\cline { 2 - 6 } & Herbaceous & $4.16(4.88)$ & $0.33(0.49)$ & $0.21(0.34)$ & $1.57(2.19)$ \\
\cline { 2 - 6 } & Litter & $1.93(2.26)$ & $2.53(3.72)$ & $1.80(2.91)$ & $2.09(2.91)$ \\
\cline { 2 - 6 } & Total & 85.29 & 68.04 & 61.95 & 71.77 \\
\hline
\end{tabular}

Table 5. Carbon content in trees and understory vegetation of Pinus massoniana plantation

\begin{tabular}{ccc}
\hline Arrangement & Project & Carbon content \\
\cline { 2 - 3 } & Trunk & $511.10 \pm 1.37$ \\
\cline { 2 - 3 } Tree layer & Bark & $521.73 \pm 1.21$ \\
\cline { 2 - 3 } & Branch & $508.77 \pm 5.53$ \\
\cline { 2 - 3 } & Conifers & $521.24 \pm 4.80$ \\
\cline { 2 - 3 } & Taproot & $492.23 \pm 4.22$ \\
\hline \multirow{2}{*}{ Shrub layer } & lateral root & $469.76 \pm 8.26$ \\
\cline { 2 - 3 } & The upper part of the ground & $471.14 \pm 6.24$ \\
\hline \multirow{2}{*}{ Herbaceous layer } & Underground part & $452.07 \pm 4.76$ \\
\cline { 2 - 3 } & The upper part of the ground & $461.84 \pm 7.47$ \\
\hline Litter layer & Underground part & $384.34 \pm 10.46$ \\
\hline
\end{tabular}

From Figure 4, it can be seen that, according to the distribution structure of the aboveground biomass, the spatial distribution sequence of the aboveground biomass is tree layer > litter layer > shrub layer > vegetation layer. The tree is the leader of the community. Although the proportion of shrub herb layer is small in the biomass of Pinus massoniana community, its good water absorption and soil conservation function have an important role in the water and soil conservation of Pinus massoniana forest. The average ratios of tree layers of shrub, vegetation, and litter are $92.06 \%, 2.84 \%, 2.19 \%$, and $2.91 \%$, respectively. The results of domestic research are slightly different, and the biomass allocation ratio of shrub layer and herb layer is similar to other research results. The allocation of the litter layer is relatively high, which may be due to the single stand structure of the Pinus massoniana plantation, which is caused by less precipitation, thin soil layer, less undergrowth vegetation, weak soil microbial activity, and slow decomposition of litter. It can be concluded that stand density is closely related to stand biomass. With the increase of the density of the stand, the total biomass of the community is decreasing, which is different from that of the previous research. The reason is the difference of the tree species and the region. But it is foreseeable that the density effect is significant in the Pinus massoniana plantation, and the stand with large density should be moderately thinned, and the proper adjustment of stand density can increase the stand biomass and carbon storage.

\subsection{Carbon content of different organs and understory vegetation of Pinus massoniana}

The carbon content of the organs of Pinus massoniana plantation is between 469.76 and $521.73 \mathrm{~g} \cdot \mathrm{kg}^{-1}$. The highest carbon content of bark is $521.73 \mathrm{~g} \cdot \mathrm{kg}^{-1}$. The needle leaf is $521.24 \mathrm{~g} \cdot \mathrm{kg}^{-1}$. The lateral root is lowest, with $469.76 \mathrm{~g} \cdot \mathrm{kg}^{-1}$. The carbon content of the aboveground and underground parts of shrub layer is $461.84 \mathrm{~g} \cdot \mathrm{kg}^{-1}$ and $384.34 \mathrm{~g} \cdot \mathrm{kg}^{-1}$, respectively. The carbon content of litter layer is $477.43 \mathrm{~g} \cdot \mathrm{kg}^{-1}$. The carbon 
content is: tree layer > shrub layer > vegetation layer > litter layer, as shown in Table 5.

Table 6. Effects of density regulation on tree storages carbon storage and distribution characteristics

\begin{tabular}{|c|c|c|c|c|c|c|c|c|}
\hline \multirow[b]{2}{*}{ Project } & \multicolumn{2}{|r|}{ CK } & \multicolumn{2}{|r|}{$\mathbf{H}$} & \multicolumn{2}{|r|}{$\mathbf{M}$} & \multicolumn{2}{|r|}{$\mathbf{L}$} \\
\hline & $\begin{array}{c}\text { Carbon } \\
\text { reserves } \\
\left(\mathrm{t} \cdot \mathrm{hm}^{-2}\right)\end{array}$ & Proportion (\%) & $\begin{array}{c}\text { Carbon } \\
\text { reserves } \\
\left(\mathrm{t} \cdot \mathrm{hm}^{-2}\right)\end{array}$ & Proportion (\%) & $\begin{array}{c}\text { Carbon } \\
\text { reserves } \\
\left(\mathrm{t} \cdot \mathrm{hm}^{-2}\right)\end{array}$ & Proportion/\% & $\begin{array}{c}\text { Carbon } \\
\text { reserves } \\
\left(\mathrm{t} \cdot \mathrm{hm}^{-2}\right)\end{array}$ & Proportion (\%) \\
\hline Trunk & 80.80 & 71.67 & 79.32 & 68.78 & 79.23 & 66.90 & 72.8 & 63.86 \\
\hline Bark & 10.27 & 9.11 & 9.35 & 8.10 & 8.99 & 7.59 & 8.22 & 7.20 \\
\hline Branch & 6.02 & 5.34 & 8.46 & 7.33 & 9.72 & 8.20 & 9.85 & 8.63 \\
\hline Conifers & 4.37 & 3.88 & 4.44 & 3.85 & 6.50 & 5.49 & 7.83 & 6.86 \\
\hline Taproot & 9.19 & 8.15 & 10.77 & 9.34 & 11.33 & 9.57 & 11.15 & 9.77 \\
\hline lateral root & 2.10 & 1.87 & 3.00 & 2.60 & 2.65 & 2.24 & 4.20 & 3.68 \\
\hline Total & 112.75 & 100.0 & 115.33 & 100.0 & 118.44 & 100.0 & 114.13 & 100.0 \\
\hline
\end{tabular}

Table 7. Effects of density regulation on understory vegetation and carbon storage in litter layer

\begin{tabular}{|c|c|c|c|c|c|}
\hline \multirow{2}{*}{ Project } & & \multicolumn{2}{|c|}{ Component } & \multicolumn{2}{|c|}{ Carbon reserves } \\
\hline & & CK & $\mathbf{H}$ & $\mathbf{M}$ & $\mathbf{L}$ \\
\hline \multirow{2}{*}{ Shrub layer } & The upper part of the ground & $1.14 \pm .0 .01$ & $1.50 \pm 0.12$ & $1.58 \pm 0.22$ & $1.58 \pm 0.17$ \\
\hline & Underground part & $0.79 \pm 0.10$ & $0.95 \pm 0.03$ & $1.11 \pm 0.05$ & $2.38 \pm 0.45$ \\
\hline \multirow{2}{*}{ Grass and tree layer } & The upper part of the ground & $0.69 \pm 0.07$ & $2.04 \pm 0.33$ & $2.32 \pm 0.02$ & $2.24 \pm 0.02$ \\
\hline & Underground part & $0.92 \pm 0.10$ & $0.93 \pm 0.12$ & $1.12 \pm 0.04$ & $1.31 \pm 0.12$ \\
\hline Litter layer & Litter & $0.30 \pm 002$ & $0.44 \pm 0.05$ & $0.57 \pm 0.03$ & $0.66 \pm 0.07$ \\
\hline
\end{tabular}

Table 8. Influence of density regulation on soil carbon storage under forest

\begin{tabular}{ccccc}
\hline Layer & CK & H & M & L \\
\hline Humic layer & $7.74 \pm 0.98$ & $9.01 \pm 0.50$ & $9.96 \pm 1.96$ & $7.72 \pm 0.89$ \\
\hline $0-15 \mathrm{~cm}$ & $42.24 \pm 5.75$ & $42.54 \pm 4.50$ & $49.51 \pm 12.51$ & $39.88 \pm 7.78$ \\
\hline $15-30 \mathrm{~cm}$ & $32.55 \pm 5.81$ & $30.88 \pm 9.09$ & $28.21 \pm 8.11$ & $23.56 \pm 3.17$ \\
\hline $30-45 \mathrm{~cm}$ & $22.85 \pm 0.42$ & $26.45 \pm 1.88$ & $22.65 \pm 8.40$ & $20.79 \pm 2.71$ \\
\hline Total & $105.38 \pm 9.25$ & $108.88 \pm 14.07$ & $110.33 \pm 29.10$ & $91.95 \pm 14.50$ \\
\hline
\end{tabular}

Table 9. Effects of density regulation on carbon storage of individual components in Pinus massoniana Plantation Ecosystem

\begin{tabular}{ccccccccc}
\hline \multirow{2}{*}{ Component } & \multicolumn{2}{c}{ CK } & \multicolumn{2}{c}{ H } & \multicolumn{2}{c}{ M } & L \\
\cline { 2 - 8 } & $\begin{array}{c}\text { Carbon } \\
\text { reserves }\end{array}$ & $\begin{array}{c}\text { Propor- } \\
\text { tion (\%) }\end{array}$ & $\begin{array}{c}\text { Carbon } \\
\text { reserves }\end{array}$ & $\begin{array}{c}\text { Propor- } \\
\text { tion (\%) }\end{array}$ & $\begin{array}{c}\text { Carbon } \\
\text { reserves }\end{array}$ & $\begin{array}{c}\text { Propor- } \\
\text { tion (\%) }\end{array}$ & $\begin{array}{c}\text { Carbon } \\
\text { reserves }\end{array}$ & $\begin{array}{c}\text { Propor- } \\
\text { tion (\%) }\end{array}$ \\
\hline Tree layer & $112.5 \pm 0.3$ & 50.8 & $115.33 \pm 0.36$ & 50.13 & $118.44 \pm 0.40$ & 50.3 & $114.13 \pm 0.38$ & 53.23 \\
\hline $\begin{array}{c}\text { Undergrowth } \\
\text { vegetation }\end{array}$ & $3.54 \pm 006$ & 1.6 & $5.42 \pm 0.22$ & 2.36 & $6.13 \pm 0.40$ & 2.6 & $7.68 \pm 0.33$ & 3.58 \\
\hline Litter layer & $0.30 \pm 0.01$ & 0.13 & $0.44 \pm 0.04$ & 0.19 & $0.57 \pm 0.20$ & 0.24 & $0.66 \pm 0.05$ & 0.31 \\
\hline Soil layer & $105.38 \pm 9.2$ & 47.47 & $\begin{array}{c}108.88 \pm 14.0 \\
7\end{array}$ & 47.32 & $\begin{array}{c}110.33 \pm 29.1 \\
0\end{array}$ & 46.86 & $91.95 \pm 14.50$ & 42.88 \\
\hline Total & $221.97 \pm 8.9$ & 100 & $\begin{array}{c}230.07 \pm 14.1 \\
5\end{array}$ & 100 & $\begin{array}{c}235.46 \pm 29.0 \\
2\end{array}$ & 100 & $214.43 \pm 15.04$ & 100 \\
\hline
\end{tabular}

\subsection{Effects of density regulation on carbon storage and allocation of Pinus massoniana plantation}

The carbon storage of Pinus massoniana stands with CK, $\mathrm{H}, \mathrm{M}$, and L density is $112.75,115.33,118.44 \mathrm{t} \cdot \mathrm{hm}^{-2}$, and $114.13 \mathrm{t} \cdot \mathrm{hm}^{-2}$, respectively, after density regulation $4 \mathrm{a}$. The carbon storage of Pinus massoniana stands with $\mathrm{H}$, $M$, and $L$ reserve density is $1.22 \%, 5.05 \%$, and $2.29 \%$ higher than CK. The largest carbon storage of the tree layer is $\mathrm{M}$ regulation, as shown in Table 6. Except for the carbon storage of bark with $\mathrm{H}, \mathrm{M}$, and $\mathrm{L}$ regulation is slightly less than $\mathrm{CK}$, and the carbon storage of all organs in Pinus massoniana stands is higher than that of CK under different reserve densities. The carbon storage allocation of tree layer of Pinus massoniana forest is basically the same under 4 kinds of reserve densities.
The largest proportion of carbon storage allocation is trunk and the proportion is $71.67 \%, 68.78 \%, 66.90 \%$, and $63.86 \%$, respectively. The second is the main root and the proportion is $8.15 \%, 9.34 \%, 9.57 \%$ and $9.77 \%$, respectively. The third is the bark and the proportion is $9.11 \%, 8.10 \%, 7.59 \%$, and $7.20 \%$, respectively. The lowest is the lateral root (all $<4 \%$ ).

3.4. Effects of density regulation on understory vegetation and carbon storage of litter layer of Pinus massoniana plantation

With the increase of the regulation intensity of Pinus massoniana plantation and the decrease of reserve density, the carbon storage of understory vegetation increases gradually. The aboveground parts of shrubs are CK $31.89 \%, 38.58 \%$, and $38.98 \%$, respectively, and 
the densities of $M$ and $L$ are basically the same. The carbon storage of the underground parts of the shrub, the underground and aboveground parts of the grass, and the litter is consistent with that of the underground parts of the shrub, as shown in Table 7.

\subsection{Effects of density regulation on carbon storage of soil} layer of Pinus massoniana plantation

The effects of 4 different reserve densities on soil carbon storage in Pinus massoniana forest are not significant (shown in Table $8, \rho>0.05$ ). The $\mathrm{M}$ density is the highest, with $(110.33 \pm 29.10) \mathrm{t} \cdot \mathrm{hm}^{-2}$. The $\mathrm{H}$ density is $(108.88 \pm 14.07) \mathrm{t} \cdot \mathrm{hm}^{-2}$. The $\mathrm{H}$ density and $\mathrm{M}$ density have no significant difference. The CK density is $(105.38 \pm 9.25) \mathrm{t} \cdot \mathrm{hm}^{-2}$, and the carbon storage of $\mathrm{L}$ reserve density is lowest, with $(91.95 \pm 14.50) t \cdot \mathrm{hm}^{-2}$. There is no significant difference in carbon storage of the same soil layer of Pinus massoniana with different reserve densities. It is known that density regulation has no significant effect on soil carbon storage. However, with the decrease of the reserve density, the soil carbon storage increases first and then decreases. The soil carbon storage of the Pinus massoniana forest with $M$ and $\mathrm{H}$ reserve density are $3.32 \%$ and $4.69 \%$ higher than that of $\mathrm{CK}$, and $\mathrm{L}$ is $12.75 \%$ lower than that of CK.

\subsection{Effects of density regulation on total carbon storage of} Pinus massoniana plantation ecosystem

After different density regulations $4 a$, the total carbon storages of Pinus massoniana plantation ecosystem change. The case of $\mathrm{CK}, \mathrm{H}, \mathrm{H}$, and $\mathrm{L}$ is 221.97, 230.07, $235.46 \mathrm{t} \cdot \mathrm{hm}^{-2}$, and $214.43 \mathrm{t} \cdot \mathrm{hm}^{-2}$, respectively. There is no significant difference between the 3 reserve densities $(H, M$, and $L)$ and $C K$. However, $H$ and $M$ increase the total carbon storage of the ecosystem compared with $\mathrm{CK}$, which are $3.65 \%$ and 6.08 , respectively. The L density is $3.40 \%$ lower than that of CK. It is shown that $\mathrm{H}$ and $\mathrm{M}$ density are beneficial to increase the total carbon storage in the ecosystem. The low reserve density is not conducive to increasing the carbon storage of the ecosystem in the short term. $\mathrm{H}, \mathrm{M}, \mathrm{L}$ regulation and $\mathrm{CK}$ Pinus massoniana forest ecosystems have the largest carbon storage in tree layer, accounting for $50.13 \%$, $50.30 \%, 53.23 \%$, and $50.80 \%$ of the total storage, respectively. The second is the soil layer, accounting for $47.32 \%, 46.86 \%, 42.88 \%$, and $47.47 \%$, respectively. The undergrowth litter layer has the smallest carbon storage, accounting for $3.58 \%, 2.60 \%, 2.36 \%$, and $1.60 \%$ of the carbon storage of the ecosystem, and the litter layer accounts for $0.31 \%, 0.24 \%, 0.19 \%$, and $0.13 \%$, respectively. The allocation of carbon storage of each component of ecosystem by density regulation is different, as shown in Table 9.

Density regulation has an effect on carbon storage of each component of ecosystem. Compared with $\mathrm{CK}$, the carbon storages of Pinus massoniana tree layer under $\mathrm{H}$, $M$, and $L$ reserve densities increased $2.29 \%, 5.04 \%$, and $1.22 \%$, respectively. Soil carbon storage increased by $3.32 \%$ and $4.69 \%$ under $M$ and $H$ reserve densities. Soil carbon storage decreased by $12.75 \%$ under $L$ density, but is not significantly different from CK. After thinning 4a, under $H, M$, and $L$ reserve densities, the carbon storage of understory vegetation and litter layer of Pinus massoniana are increased. The understory vegetation layer increased by $116.91 \%, 73.12 \%$, and $52.99 \%$, respectively, compared with CK. Litter layer increased by $124 \%, 92 \%$, and $48.88 \%$, respectively, compared with CK. The carbon storage of understory vegetation and litter layer is significantly different from that of CK. Density regulation promotes the accumulation of carbon storage of Pinus massoniana trees, and increases the carbon storage of understory vegetation, litter, and soil layer.

\subsection{Effects of stand density on carbon storage of Pinus massoniana plantation}

The research results of this paper show that stand density has a significant effect on the ecosystem of Pinus massoniana plantation. Suitable forest density can increase forest carbon sink. The average carbon storages per unit area of Pinus massoniana plantation with three different stand densities are $94.11 \mathrm{t} / \mathrm{tm}^{2}(1679$ plants $\left.\mathrm{t} / \mathrm{hm}^{2}\right), \quad 79.06 \mathrm{t} / \mathrm{tm}^{2}\left(2250\right.$ plants $\left./ \mathrm{hm}^{2}\right)$, and 73.32 $\mathrm{t} / \mathrm{tm}^{2}\left(2800\right.$ plants $\left./ \mathrm{hm}^{2}\right)$. The carbon storage of tree layer and soil layer of Pinus massoniana plantation changed most significantly. With the increase of stand density, the proportion of tree layer carbon storage decreased gradually in the Platycladus orientalis plantation. This is caused by the large the stand density, the more trees grown in the Pinus massoniana plantation, the smaller average DBH of the stand, and the decreased biomass of single plant of the tree. With the increase of stand density, the proportion of soil layer carbon storage in the Platycladus orientalis plantation ecosystem decreased first and then increased. The reason may be due to the larger interference from the selected Platycladus orientalis stand sample plot with medium density, the more active forest animals, and more disturbances to the litter and the herbaceous shrubs.

Dong Peng and Li Zhao researched the stand structure and stand density of Pinus massoniana plantation, and concluded that the reasonable stand should be 2325 plants $/ \mathrm{hm}^{2}-3225$ plants $/ \mathrm{hm}^{2}$. Comparing with the research results of this paper, it can be seen that the density of Pinus massoniana plantation can be lower. The carbon storage in the ecological system of Pinus massoniana with the stand density 1679 plants $/ \mathrm{hm}^{2}$ are higher than the stand density of 2250 plants $/ \mathrm{hm}^{2}$, so that the thinning of the dense forest can enhance the carbon storage of the ecological system of Pinus massoniana plantation.

There is a close relationship between stand density and stand biomass and carbon storage. With the same stand age and site condition, as the decrease of the stand density, the individual space in the stand increases and the illumination condition improves, which makes the growth space of the individual increase, the volume of the tree crown increases, and the biomass of the tree leaves increases. Meanwhile, the ground surface temperature of the stand with small stand density is relatively high, which promotes the activity of soil 
microbes, accelerates the decomposition, improves the soil fertility and is beneficial to the growth of the tree. It reflects the growth of the individual breast height diameter and the tree height for the low density forest. Reasonable stand density improves forest productivity, and is conducive to the accumulation of biomass and carbon storage, so as to better play the function of forest carbon sink.

The total carbon storage of Pinus massoniana plantation in 16 years under $H, M$ and $L$ and CK conditions is 230.07, 235.46, $214.43 \mathrm{t} \cdot \mathrm{hm}^{-2}$, and $221.97 \mathrm{t} \cdot \mathrm{hm}^{-2}$, respectively. Density regulation increases total carbon storage of Pinus massoniana plantation ecosystem, but the difference is not significant. Different density regulation had certain effects on the composition of carbon storage in Pinus massoniana plantation ecosystem. The increase of carbon storage of the tree layer requires reasonable reserve density. The carbon storage of Pinus massoniana forest with $\mathrm{H}$ and $\mathrm{M}$ density increased by $3.65 \%$ and $6.8 \%$ compared with $\mathrm{CK}$, while $\mathrm{L}$ density decreased by $3.40 \%$. This is consistent with the results of thinning experiments of 30 year Pinus tabulaeformis plantation with different intensities. High intensity thinning and moderate intensity thinning can improve carbon storage of Pinus tabulaeformis plantation. The increase of the carbon storage of the tree layer is mainly by the density regulation to improve the stand environment, reduce the crown density, improve the nutrition space of the growth of Pinus massoniana, and promote the growth of the stand and the accumulation of biomass. The operation of $\mathrm{M}$ density 1566 plants $/ \mathrm{hm}^{-2}$ is most conducive to the increase of carbon storage of the tree layer. The carbon storage of $L$ density is mainly due to short regulation time and relatively few trees. Density regulation is beneficial to the improvement of stand productivity, and different species of Pinus massoniana, Cunninghamia lanceolata, megakanium and Castanopsis are verified. By increasing density, the carbon storage of the tree stand increased which provides an effective measure to increase the density of plantation.

Density regulation does not significantly affect carbon storage and allocation of organs of Pinus massoniana. For $\mathrm{H}, \mathrm{M}$ and $\mathrm{L}$ density treatments and $\mathrm{CK}$, the carbon storage of the tree layer of tree trunk is largest, which accounts for $68.78 \%, 66.90 \%, 63.86 \%$, and $71.67 \%$ respectively. Bark $>$ roots $>$ branches and leaves. The smallest proportion is lateral root, which is basically consistent with previous researches, and may be determined by the characteristics of the species. By contrast, the lower proportion of carbon storage of tree layer in the low density stand is trunk. The reason is that low density increases the light transmittance of the stand, is beneficial to the growth of lateral branches, increases the carbon accumulation of branches and leaves, and reduces the allocation of biomass of the tree layer. Density regulation has no significant change in soil carbon storage. The soil carbon storage of CK is higher than $\mathrm{L}$ density treatment, $\mathrm{H}$ and $\mathrm{M}$ density treatment is higher than CK. The reasonable management of density is conducive to increasing soil carbon storage, and if the density is too small, the carbon storage of the soil layer will be reduced. Although biomass of trees and understory vegetation increases under $L$ density, the carbon storage of ecosystem is not significantly different due to the number of reserved plants (Liew et al., 2018; Ouyang et al., 2017). In the process of density regulation, a large number of woods are removed, some small branches and leaves have not been cleaned up, and the amount of litter on the woodland is increased to introduce the carbon source of the soil, which may be the reason for the increase of soil carbon storage. For $L$ density, soil carbon storage is decreased, which may be the destruction of soil structure during the removal of thinning wood, thereby reducing the soil carbon pool.

After density regulation $4 a$, the carbon storage of vegetation under various treatments is $3.54-7.68 \mathrm{t} \cdot \mathrm{hm}^{-2}$, which accounts for $1.60 \%-3.58 \%$ of the ecosystem. The carbon storage of litter is $0.30-0.66 \mathrm{t} \cdot \mathrm{hm}^{-2}$, which accounts for $0.13 \%-0.31 \%$. The carbon storage of the undergrowth and litter layer are less in the ecosystem, but play an important role in the accumulation of soil carbon storage and carbon cycle in the ecosystem. Density is inversely proportional to the carbon storage of the understory vegetation and litter. There is a significant difference in carbon storage between litter and CK. Carbon storage of Pinus massoniana plantation ecosystem is the largest under medium density regulation. Therefore, the reserve density 1566 plants $/ \mathrm{hm}^{-2}$ is suitable for the middle age forest of Pinus massoniana.

\subsection{Effects of thinning on carbon storage of Pinus massoniana plantation}

The carbon storage of Pinus massoniana plantations is significantly different after different thinning. It is also possible to predict the appropriate thinning intensity to increase the carbon storage of the system. Research results show: The carbon storage of Pinus massoniana with thinning two times $76.36 \mathrm{t} / \mathrm{hm}^{2}>$ The carbon storage of Pinus massoniana with thinning one time $37.35 \mathrm{t} / \mathrm{hm}^{2}>$ The carbon storage of Pinus massoniana with non-thinning $68.54 \mathrm{t} / \mathrm{hm}^{2}$. The carbon storage of the tree layer is: Thinning one time $37.35 \mathrm{t} / \mathrm{hm}^{2}>$ Thinning two times $30.42 \mathrm{t} / \mathrm{hm}^{2}>$ Non-thinning 28.13 $\mathrm{t} / \mathrm{hm}^{2}$ (Jiang et al., 2017; Li et al., 2017). The carbon storage of soil layer with thinning two times $39.38 \mathrm{t} / \mathrm{hm}^{2}$ is higher than non-thinning $36.09 \mathrm{t} / \mathrm{hm}^{2}$ and thinning one time $32.47 \mathrm{t} / \mathrm{hm}^{2}$. The carbon storage of the tree layer decreases, which accounts for only $39.84 \%$ of the system. Because the number of standing trees decreases after thinning and Platycladus orientalis belongs to slow growing trees, the longer thinning intensity needs longer time to recover. Therefore, the carbon storage with thinning two times is less increased. The biomass and total biomass of the organs of Platycladus orientalis after thinning one time and thinning two times are higher than that of the non-thinned woodland. The biomass of tree trunk increases most obviously. After thinning two times, the biomass of individual tree trunk is 1.05 times that of non-thinning. It is mainly because the thinning provides more space for the individual, the 
intraspecific competition is slowed down, the light in the forest is full, the photosynthesis is more effective, and the accumulation of organic matter increases faster. The contribution of soil thinning to carbon storage of the soil layer is more than that without thinning.

Thinning affects biomass and carbon storage of the forest by influencing the biomass and carbon storage of tree layer, shrub layer, herb layer, and litter layer. After thinning, the biomass of trees increased, but the total biomass decreased. Some scholars have also researched the relationship between the intensity of thinning and the biomass of the stand. After the thinning, the growth indexes of the Pinus tabulaeformis forest are both high intensity thinning $>$ moderate intensity thinning $>$ weak intensity thinning > control. Moderate and high intensity thinning are significantly greater than control and weak thinning. In the growth process of the forest, two kinds of effects are produced by thinning. One is the growth effect of the stand due to the expansion of the growth space of forest trees, and the other is the loss effect of thinning out some trees. Therefore, the effect of thinning on stand productivity and factors depends on the relative size of the above two effects. When researching the effects of thinning on stand productivity and factors, it is necessary to decide on the specific conditions. There are different views on the effects of thinning on total biomass and carbon storage of plantation. This is because the total forest biomass and carbon storage are composed of tree layer, shrub layer, herbaceous layer, litter layer, and soil layer, and each layer also has interaction and relationship, so the law of change is more complex.

\section{Conclusions}

In this paper, density control experiments of Pinus massoniana with different densities were conducted to research the effects of stand density on the allocation of ecosystem carbon storage. The results show that different density regulation has certain effects on the composition of carbon storage of Pinus massoniana plantation ecosystem and density regulation is beneficial to the improvement of stand productivity. Many species of Pinus massoniana, Cunninghamia lanceolata, megakanium, and Castanopsis were verified. Increase of carbon storage of tree stand is achieved by increasing density regulation. Appropriate thinning intensity has a significant effect on increasing carbon storage of the system. Thinning provides more space for individuals to grow, and the competition within species decreases slowly. The forest light is sufficient, photosynthesis is more effective, and organic matter accumulation increases faster. Then the accumulation of individual biomass and carbon storage increased significantly than that of un-thinned plots.

\section{Authors' Contributions}

Yanli Du: Modelling and optimization, writing of manuscript.

\section{References}

Ahamed M.S., Guo H. and Tanino K. (2018), A quasi-steady state model for predicting the heating requirements of conventional greenhouses in cold regions, Information Processing in Agriculture. 5, 33-46.

Al-zaqri N., Alsalme A., Adil S.F., Alsale A., Alshammari S.G., Alresayes S.I., Alotaibi R., Al-Kinany M. and Siddiqui M.R.H. (2017), Comparative catalytic evaluation of nickel and cobalt substituted phosphomolybdic acid catalyst supported on silica for hydrodesulfurization of thiophene, Journal of Saudi Chemical Society, 21, 965-973.

Anderegg, W.R., Schwalm C. and Biondi F. (2015), Forest Ecology. Pervasive drought legacies in forest ecosystems and their implications for carbon cycle models, Science, 349, 528-532.

Bell T.E., Gonzalez-Carballo J.M., Tooze R.P. and TorrenteMurciano L. (2018), High yield manufacturing of gamma- $-\mathrm{Al}_{2} \mathrm{O}_{3}$ nanorods, ACS Sustainable Chemistry and Engineering, 6, 8892.

Bharati S., Joshi B., Dhakal R., Paneru S., Dhakal S.C. and Joshi K.R. (2020), Effect Of Different Mulching On Yield And Yield Attributes Of Potato In Dadeldhura District, Nepal, Malaysian Journal of Sustainable Agriculture, 4, 54-58.

Boudreault, C., Drapeau P. and Bouchard M. (2015), Contrasting responses of epiphytic and terricolous lichens to variations in forest characteristics in northern boreal ecosystems 1, Canadian Journal of Forest Research. 45, 595-606.

Cicuzza D., Nicola C.D. and Testi A. (2010), Which is the contribution to the carbon sequestration of the forest ecosystems in the Castelporziano Reserve Evidences from an integrated study on humus and vegetation, Rendiconti Lincei, 26, 403-411.

Fei, X., Song Q. and Zhang Y. (2017), Carbon exchanges and their responses to temperature and precipitation in forest ecosystems in Yunnan, Southwest China, Science of the Total Environment, 616, 824-840.

Fischer R., Bohn F. and Paula M.D.D. (2016), Lessons learned from applying a forest gap model to understand ecosystem and carbon dynamics of complex tropical forests, Ecological Modelling, 326, 124-133.

Gohar R., Ain Q.T., Zaheer M., Liulei B. and Javed I. (2019), An analysis of two-dimensional flow through a water reservoir using mathematical approach, Environmental Contaminants Reviews, 2, 11-13.

Gonzalez-Trinidad J., Junez-Ferreira H.E., Pacheco-Guerrero A., Olmos-Trujillo E. and Bautista-Capetillo C.F. (2017), Dynamics of land cover changes and delineation of groundwater recharge potential sites in the aguanaval aquifer, zacatecas, mexico, Applied Ecology and Environmental Research, 15, 387-402.

Hao G., Zhuang Q. and Zhu Q. (2015), Quantifying microbial ecophysiological effects on the carbon fluxes of forest ecosystems over the conterminous United States, Climatic Change, 133, 695-708.

Hu H., Yang Y. and Fang J. (2016), Toward accurate accounting of ecosystem carbon stock in China's forests, Science Bulletin. 61,1-2.

Ibrahim S., Magaji J.I. and Isa Z. (2020), Simulation of sediment yield and supply on water flow in different subbasins of terengganu watershed from 1973-2017, Water Conservation and Management, 4, 1-6.

Igu N.I. and Marchant R. (2016), Aboveground carbon storage in a freshwater swamp forest ecosystem in the Niger Delta, Carbon Management, 7, 137-148. 
Ilyas M., Ali M.A., Awan A.N., Haider S. and Shahid A. (2019), Estimation of noise levels in the road side parks and study of its impacts on health of visitors in Faisalabad, Earth Sciences Pakistan, 14-22.

Isfarita I., Husain M.L., Satyanarayana B., Ibrahim S. and Zakaria R. (2019), Root density analysis and wave attenuation ability of Rhizophora species at Kemaman, Terengganu, Earth Sciences Malaysia, 3, 18-24

Jiang S.C., Ge S.B., Wu X., Yang Y.M., Chen J.T. and Peng W.X. (2017), Treating $n$-butane by activated carbon and metal oxides, Toxicological and Environmental Chemistry, 99, 753759.

Keshavarzi A. and Kumar V. (2020), Spatial distribution and potential ecological risk assessment of heavy metals in agricultural soils of Northeastern Iran, Geology, Ecology, and Landscapes, 4, 87-103.

Khaleel C., Tabanca N. and Buchbauer G. (2018), Alpha-terpineol, a natural monoterpene: a review of its biological properties, Open Chemistry, 16, 349-361.

Kim N.Y., Jeon E.J., Jung S.H., Ahn S.J., Park M.A. and Seo J.S. (2018), Gene expression profiling and expression analysis of freshwater shrimp (neocaridina denticulata denticulata) using expressed sequence tags and short-term exposure to copper, Journal of Environmental Biology, 39, 51-57.

Li D., Wang L., Peng W., Ge S., Li N. and Furuta Y. (2017), Chemical structure of hemicellulosic polymers isolated from bamboo bio-composite during mold pressing, Polymer Composites, 38, 2009-2015.

Liew R.K., Chong M.Y., Osazuwa O.U., Nam W.L., Phang X.Y., Su M.H., Cheng C.K., Chong C.T. and Lam S.S. (2018), Production of activated carbon as catalyst support by microwave pyrolysis of palm kernel shell: a comparative study of chemical versus physical activation, Research on Chemical Intermediates, 44, 3849-3865.

Liu Z. (2017), China's plans and policies for reducing $\mathrm{CO}_{2}$ emission from biomass-fired power plants: modeling and economic study, Energy Sources Part B-Economics Planning and Policy, 12, 1001-1006.

Lun F., Liu Y. and He L. (2018), Life cycle research on the carbon budget of the Larix principis-rupprechtii, plantation forest ecosystem in North China, Journal of Cleaner Production, 177, 178-186.

Ma J., Bu R. and Liu M. (2015), Ecosystem carbon storage distribution between plant and soil in different forest types in Northeastern China, Ecological Engineering, 81, 353-362.

Mackay D.S. and Band L.E. (2015), Forest ecosystem processes at the watershed scale: dynamic coupling of distributed hydrology and canopy growth, Hydrological Processes, 11, 1197-1217.

Maksimova E. and Abakumov E. (2015), Wildfire effects on ash composition and biological properties of soils in foreststeppe ecosystems of Russia, Environmental Earth Sciences, 74, 1-11.

Mjöfors K., Strömgren M. and Nohrstedt H. (2017), Indications that site preparation increases forest ecosystem carbon stocks in the long-term, Scandinavian Journal of Forest Research, 32, 1-34.

Mocan A., Fernandes A., Barros L., Crisan G., Smiljkovic M., Sokovic M. and Ferreira I.C.F.R. (2018), Chemical composition and bioactive properties of the wild mushroom polyporus squamosus (huds.) Fr: A study with samples from Romania, Food \& Function, 9, 160-170.

Muhammad Tariq S., Zhan Han H. and Maqbool A. (2019), Causes and control measures of urban air pollution in China, Environment \& Ecosystem Science, 3, 35-36.

Nisavic M., Stoiljkovic M., Crnolatac I., Milosevic M., Rilak A. and Masnikosa R. (2018), Highly water-soluble ruthenium(ii) terpyridine coordination compounds form stable adducts with blood-borne metal transporting proteins, Arabian Journal of Chemistry, 11, 291-304.

Ogwah C. and Eyankware M.O. (2020), Investigation of hydrogeochemical processes in groundwater resources located around abandoned okpara coal mine, Enugu Se. Nigeria, Journal Clean Was, 4, 12-16.

Ouyang H., Hou K., Wang L. and Peng W. (2017), Optimization protocol for the microwave-assisted extraction of antioxidant components from pinus elliottii needles using response surface methodology, BioResources, 12, 478-494.

Sanchez Camacho E.A. and Martinez Morales M. (2017), Estimation of the volume of underground water for a coastal wetland, Revista Internacional De Contaminacion Ambiental, 33, 65-76.

Schmerbeck J. and Fiener P. (2015), Wildfires, ecosystem services, and biodiversity in tropical dry forest in India, Environmental Management, 56, 355-372.

Shrestha R.K., Strahm B.D. and Sucre E.B. (2015), Greenhouse gas emissions in response to nitrogen fertilization in managed forest ecosystems, New Forests, 46, 167--93.

Spielvogel S., Prietzel J. and Kögel-Knabner I. (2016), Stand scale variability of topsoil organic matter composition in a highelevation Norway spruce forest ecosystem, Geoderma, 267, 112-122.

Vicente-Molina M.A., Fernandez-Sainz A. and Izagirre-Olaizola J. (2018), Does gender make a difference in pro-environmental behavior The case of the basque country university students, Journal of Cleaner Production, 176, 89-98.

Viglietti D., Freppaz M. and Filippa G. (2005), Soil C and N response to changes in winter precipitation in a subalpine forest ecosystem, NW Italy, Hydrological Processes, 28, 5309-5321.

Wang L., Ge S., Liu Z., Zhou Y., Yang X., Yang W., Li D. and Peng W. (2018), Properties of antibacterial bioboard from bamboo macromolecule by hot press, Saudi Journal of Biological Sciences, 25, 465-468.

Yan J., Li K. and Wang W. (2015), Changes in dissolved organic carbon and total dissolved nitrogen fluxes across subtropical forest ecosystems at different successional stages, Water Resources Research, 51, 3681-3694.

Yuan Y., Zhao Z. and Zhang P. (2017), Soil organic carbon and nitrogen pools in reclaimed mine soils under forest and cropland ecosystems in the Loess Plateau, China, Ecological Engineering, 102, 137-144.

Zhang J., Peng C. and Zhu Q. (2016), Temperature sensitivity of soil carbon dioxide and nitrous oxide emissions in mountain forest and meadow ecosystems in China, Atmospheric Environment, 142, 340-350. 